\title{
Haiti 2010 Earthquake-How to Explain Such Huge Losses?
}

\author{
Laurent Hou ${ }^{1,2, *}$ and Peijun Shi ${ }^{2,3,4}$ \\ ${ }^{1}$ Paris 4 University (Sorbonne), ENEC (Espace, Nature et Culture), 1 rue Victor Cousin, 75005 Paris, France \\ ${ }^{2}$ State Key Laboratory of Earth Surface Processes and Resource Ecology, Beijing Normal University, Beijing 100875, China \\ ${ }^{3}$ Key Laboratory of Environmental Change and Natural Disasters, Ministry of Education of China, Beijing Normal University, \\ Beijing 100875, China \\ ${ }^{4}$ Academy of Disaster Reduction and Emergency Management, Ministry of Civil Affairs and Ministry of Education of China, \\ Beijing Normal University, Beijing 100875, China
}

\begin{abstract}
This article provides an overview of the 7.0 magnitude earthquake that struck Haiti on 12 January 2010, with emphasis on the disaster losses. This catastrophic event has entered world history as one of the most destructive earthquakes on record. Yet, we only have a very incomplete idea of the losses it caused. Conflicting estimates have been published by different institutions, organizations, and individuals. The article tries to present the reasons why this event, which was a strong but not an exceptional earthquake, has caused so much devastation.
\end{abstract}

Keywords disaster losses, disaster response, earthquake, Haiti, vulnerability

\section{Introduction}

On 12 January 2010, a 7.0 magnitude earthquake struck Haiti, triggering a huge disaster with dreadful human and economic losses that afflicted the poorest country of the northern hemisphere. Endemic poverty is certainly the main reason why the country encountered so many difficulties in responding to the disaster and suffered such terrible losses. Haiti's vulnerability is not only an economic issue, but also has its roots in the social and political characteristics of the country. More than one year after the occurrence of the earthquake, this article reflects on the reasons that explain the impact of the earthquake, looking both at structural features of Haiti's society and government and at the organization of disaster response. An analysis of the losses caused by a massive disaster is always a major challenge because of the difficulty of getting reliable data, a problem that is even more acute in developing countries. Beyond numbers, it is difficult to assess what such losses mean for the country, how they can be explained, and whether or not the disaster response managed to face the challenges and why.

\footnotetext{
* Corresponding author. E-mail: laurent.hou@gmail.com
}

\section{A Powerful Earthquake Striking a Very Densely Populated and Poor Area}

\subsection{Haiti's Magnitude 7.0 Earthquake: A Strong but Common Seismic Event at World Scale}

Haiti is located in a seismic area that corresponds to the boundary between the Caribbean and the North American plates. The Enriquillo fault ruptured on 12 January 2010 at 4:53 p.m. local time and generated tremors that lasted about 35 seconds - most of the energy was released during a 15 second period (RMS 2010). With the hypocenter located at a depth of $13 \mathrm{~km}$, this was a shallow earthquake. The depth of an earthquake has a significant influence on the damage it causes. Shallow earthquakes hit the surface more powerfully than deep ones and are therefore more destructive. While Haiti's earthquake had no precursors, it was followed by about 50 aftershocks with magnitudes over 4.0 during the eight days that followed the main earthquake. The most powerful aftershock had a magnitude of about 6.0 (Lacassin et al. 2010). These aftershocks did not cause a significant amount of additional damage but are reported to have spread fear among the Haitian people.

Although a significant event by its magnitude, the Haitian earthquake is not an exceptional phenomenon. According to the United States Geological Survey (USGS 2011a), 15 earthquakes with a magnitude between 7 and 7.9 happen every year in the world (average based on observations since 1900). In spite of this, the maximum intensity of this earthquake reached X on the Modified Mercalli Scale (the maximum is XII for total devastation), which corresponds to a situation in which some well-built wooden structures are destroyed, most masonry and frame structures are destroyed with foundations and rails bent (USGS 2011b). Among the ten most destructive earthquakes of the last two decades, Haiti's 2010 earthquake is the smallest. It clearly suggests that the most important reasons that explain the huge losses caused by this event are not related to the geophysical agent in itself, a view that has been briefly but efficiently presented 
by Bilham (2010) who showed that damage caused by significant earthquakes since 1900 is not proportional to magnitude and called for a UN enforcement of building codes. The comparison between Haiti's earthquake and the 7.3 magnitude Kobe earthquake in 1995 (Table 1) also shows that damage is not directly determined by the magnitude of the seismic event that triggered the disaster.

Among notable recent earthquakes, the Kobe earthquake is the closest seismic event to Haiti's because the magnitude, depth, distance of the epicenter from very populated areas, population of affected cities, and number of affected people are comparable. In spite of this, earthquake losses in Haiti have been far more severe than those experienced in Kobe, which clearly shows how vulnerable Haiti is. Only economic losses were higher from the earthquake in Kobe, which ranks as the world's most costly earthquake on record. But such economic losses cannot be easily compared. In the case of Japan which has a much more developed economy, most of the losses were not directly related to basic needs. Economic losses in Haiti have been particularly severe because they correspond to elementary necessities and have a debilitating impact on people's lives.

Past seismicity, disaster knowledge, and awareness are three closely related issues that can have an impact on the efficiency of disaster prevention and emergency planning and therefore on disaster losses. Seismologists and geologistsfrom Haiti as well as internationally renowned expertsall know that Haiti is located in a seismic area and that the island of Hispaniola has experienced significant earthquakes

Table 1. Haiti 2010 and Kobe 1995 earthquakes: similar seismic events with different consequences

\begin{tabular}{|c|c|c|}
\hline & $\begin{array}{c}\text { Haiti } 2010 \\
\text { (Port-au-Prince) }\end{array}$ & $\begin{array}{l}\text { Japan } 1995 \\
\text { (Kobe) }\end{array}$ \\
\hline Date & 12 January 2010 & 17 January 1995 \\
\hline Earthquake magnitude & $7^{\mathrm{a}}$ & $7.3^{\mathrm{g}}$ \\
\hline Depth $(\mathrm{km})$ & $13^{\mathrm{a}}$ & $16^{\mathrm{g}}$ \\
\hline Epicenter distance to city $(\mathrm{km})$ & $25^{\mathrm{a}}$ & $20^{\mathrm{g}}$ \\
\hline $\begin{array}{l}\text { Population of affected city } \\
\text { (million inhabitants) }\end{array}$ & 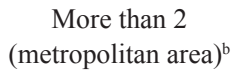 & About $1.5^{\mathrm{h}}$ \\
\hline $\begin{array}{l}\text { Population density of affected } \\
\text { city (inhabitants } \mathrm{km}^{-2} \text { ) }\end{array}$ & $24,305^{\mathrm{b}}$ & $2773^{\mathrm{h}}$ \\
\hline Deaths & $223,000^{c}$ & $6434^{\mathrm{g}}$ \\
\hline Injured & $300,000^{\mathrm{d}}$ & $40,000^{i}$ \\
\hline Homeless people & $1,300,000^{\mathrm{e}}$ & $300,000^{\mathrm{i}}$ \\
\hline Affected people & $3,200,000^{\mathrm{d}}$ & $2,000,000^{j}$ \\
\hline $\begin{array}{l}\text { Direct economic losses (billion } \\
\text { USD, adjusted to } 2010 \text { dollar } \\
\text { values) }\end{array}$ & $8-14^{\mathrm{c}, \mathrm{f}}$ & $187.44^{\mathrm{k}}$ \\
\hline
\end{tabular}

Sources: aUSGS 2010; 매SI 2009; 'EM-DAT 2011; dDaniell 2011; ${ }^{\mathrm{e}}$ Government of the Republic of Haiti 2010a; 'Cavallo, Powell, and Becerra 2010; 9USGS 1996; 'Kobe City Official Website 2011 (The number corresponds to the 2008 population. The page featuring 1995 figures is unavailable now; yet, the city population is almost the same as it was in 1995 just before the earthquake. The population slightly decreased after the disaster, but grew back to the 1995 level.); 'Encyclopædia Britannica Online 2011; 'Asian Disaster Reduction Center 2002; ' Guha-Sapir, Hargitt, and Hoyois 2003. throughout its history. In a 2008 report, Haitian geologist Claude Prépetit cites 18 major earthquakes that occurred in Haiti between 1564 and 1789 (Prépetit 2008). Of these, 15 occurred during the eighteenth century. The earthquakes of 1751 and 1770 both severely affected Port-au-Prince, and the 1770 earthquake that destroyed the still young city only recently incorporated in 1749 is often referred to as the "Port-au-Prince earthquake." This event was likely caused by the Enriquillo fault, although seismologists cannot be absolutely positive about this (Lacassin et al. 2010). Even though some more recent earthquakes have struck Haiti $(1860,1918,1922,1956,1962)$, none of them entered collective memory and, prior to the 2010 earthquake, the Haitian people did not live with earthquake risk on their minds. The focus was on hurricane prevention and response and, to a lesser extent, on floods and droughts, while earthquakes ranked quite low on the agenda. Even worse, measures taken to fight hurricane damage mainly involved building concrete houses. This has increased earthquake damage because no earthquake resistance norm was applied. These heavy buildings turned to traps that collapsed onto their occupants who would have had a better chance to escape if they had lived in lighter buildings. There has been an important gap between expert knowledge and people's behavior and awareness. Claude Prépetit who worried both about the risk and about the low level of awareness of the Haitian people had tried to warn the authorities and the public through his report and public statements in newspapers (Prépetit 2009) but his worries did not get the attention they deserved.

\subsection{A Disaster Striking the Core of the Country-Port-au-Prince's Metropolitan Area}

Although the epicenter of the earthquake was located in a rural area $25 \mathrm{~km}$ away from Haiti's capital city Port-au-Prince, the disaster affected very densely populated areas. According to World Bank statistics (World Bank 2009), Haiti's population reached about 10 million people in 2009. The average population density was estimated at 355.9 inhabitants $\mathrm{km}^{-2}$. But population density is much higher in Port-au-Prince where, according to the 2009 figures produced by IHSI (Institut Haitien de Statistique et d'Informatique 2009), the total population reached 875,978 , with a population density of 24,305 inhabitants $\mathrm{km}^{-2}$. The metropolitan area's population is estimated at over 2 million people (it has grown considerably since the last 2003 census that estimated $1,728,100$ people). This makes Port-au-Prince the largest city of Haiti by far. Its importance is even more striking from an economic point of view. The city accounts for more than 65 percent of Haiti's total economic activity and 85 percent of Haiti's tax revenues (Government of the Republic of Haiti 2010b). The main harbor and airport are also both located in Port-au-Prince. The city is the political core of the country where all important institutions are concentrated. The Haitian government and MINUSTAH (United Nations Stabilization Mission in Haiti) are based in Port-au-Prince 
and the now destroyed presidential palace used to be an object of national pride. Thus, the exposure to the earthquake disaster was particularly high because the disaster struck the heart of the country, a region that concentrates people as well as wealth and prestigious functions.

\subsection{A Disaster Striking a Poor and Extremely Vulnerable Country}

Haiti's vulnerability to disasters is essentially related to the very weak development level of this country, which is known as the poorest of the northern hemisphere. It has been widely acknowledged that the poorer a country, the more it suffers from natural disasters. Developing countries suffer more casualties, a higher number of affected people, and bigger losses than developed countries (Noy 2009). Some basic statistics show how poor the country is. Haitian GDP (Gross Domestic Product) reached 12.15 billion USD in 2009 and GDP per capita was about 1200 USD in the same year (CIA 2011). The country's 2008 HDI (Human Development Index) was 0.54; Haiti ranked 145 out of 169 countries studied. Under these circumstances, the country does not have enough resources to prevent and respond to disasters effectively. Daniell (2011) has shown that the lower a country's HDI is, the higher earthquake death tolls are. Countries with a HDI lower than 0.65 experienced more than 500 deaths on average per damaging earthquake since 1900 , whereas those with a HDI between 0.65 and 0.799 only experienced about 330 deaths on average, and those with a HDI of more than 0.8 experienced less than 20 deaths. In addition to endemic poverty, Haiti is also plagued by a high level of inequality. In 2001, its GINI (Global Inequality Index) was 59.2; Haiti ranked seventh highest inequality index out of 189 countries studied (CIA 2011). More recent statistics are unavailable, but inequality remains a very important issue that the moderate economic growth that took place from 2005 to the occurrence of the 2010 earthquake had not adequately addressed. Moreover, institutions do not work properly either; the country's corruption level ranking at 168 is among the worst in the world (Transparency International 2011).

\section{Huge Losses: The Tragedy of a Disaster Striking a Poor Country}

\subsection{What Do We Really Know about the Disaster Losses?}

One thing is certain: the earthquake was absolutely dreadful. But how dreadful was it? Answering this question is an important research challenge. Designing post-disaster plans requires as accurate an estimate as possible of the losses, and we also need good data to better understand disasters. Otherwise, research work will lead to imprecise or misleading results. The reliability of disaster statistics is a recurrent concern, but this problem is even more serious in poor countries than in developed or relatively developed ones. The extent of damage, poor administrative structures, informal burial and mass graves all make an accurate counting of the number of victims a near impossible task. Moreover, official data put out by the government did not provide much explanation and no report was issued by IHSI or any other specialized institutions.

The official death toll of 316,000 has been questioned by Radio Netherlands, which published a report on this topic (Melissen 2010) as well as by the CATDAT (Integrated Historical Global Catastrophe Database) 2010 report (Daniell 2011). Confronted with different loss estimates, we decided to group them in Table 2 . We simply cannot know precisely this disaster's death toll and the margin of possible error is very important. The Haitian government has an interest in maximizing losses in order to get more support from the international community, though nothing proves that the data $(316,000)$ were voluntarily exaggerated. But the lack of information about this issue is troubling. At the other end, the estimate provided by Radio Netherlands seems to be surprisingly low (between 50,000 and 92,000 deaths) compared to most of the other estimates that all exceed 200,000 deaths. Not many estimates of injuries are available. The only ones we found were around 300,000 people.

The number of affected people is also in question. The Red Cross estimate of 3 million affected people published as early as 14 January 2010 (ICRC 2010) has often been quoted by different sources but it does not mean that it is reliable. The CATDAT report is more cautious and gives a range between 3 million and 4.5 million. Surprisingly, the estimate provided by the government in its official Action Plan for National Recovery and Development of Haiti is much lower: 1.5 million "directly" affected people (Government of the Republic of Haiti 2010a). The expression "directly affected people" suggests that another counting method might have been used, which could explain the difference between this figure and other estimates.

Economic losses are also difficult to assess. The most commonly quoted estimate is 8 billion USD in direct losses, but a survey of the Inter-American Development Bank (Cavallo, Powell, and Becerra 2010) estimated that the direct economic losses amount to 13.9 billion USD. Damaged buildings are easier to count than affected people, but estimates might also vary depending on the definition of damage. Table 2 sums up the different estimates about the Haitian earthquake.

Although we tend to consider the CATDAT report more credible than other estimates because it provides explanations and a cautious range rather than a single number when uncertainty is prominent, we are unable to determine Haiti's real earthquake losses. This situation poses many research problems; interpretations of the disaster can significantly vary depending on the estimates used for study. These difficulties of assessing the situation accurately are also a problem for decision makers and planners who have to deal with significant uncertainties. 
Table 2. Conflicting estimates of Haiti's 2010 earthquake losses

\begin{tabular}{|c|c|c|c|c|c|c|c|}
\hline & $\begin{array}{c}\text { Haitian } \\
\text { government }\end{array}$ & Action Plan ${ }^{b}$ & CATDAT $^{\mathrm{c}}$ & EM-DAT $^{d}$ & Munich $\operatorname{Re}^{e}$ & $\begin{array}{c}\text { Radio Netherlands } \\
\text { survey }\end{array}$ & $\begin{array}{r}\text { RMS } 36 \mathrm{~h} \\
\text { estimate }^{\mathrm{g}}\end{array}$ \\
\hline Deaths (thousands) & 316 & more than 300 & $\begin{array}{c}92-220 \\
\text { best: } 162\end{array}$ & 223 & 223 & $50-92$ & 250 \\
\hline Injured (thousands) & 300 & ND & 311 & ND & ND & ND & ND \\
\hline Homeless (thousands) & ND & 1300 & $\begin{array}{c}1000-2100 \\
\text { best: } 1850\end{array}$ & ND & ND & ND & ND \\
\hline $\begin{array}{l}\text { Direct economic losses } \\
\text { (billion USD) }\end{array}$ & ND & ND & $\begin{array}{l}7.5-8.5 \\
\text { best: } 7.8\end{array}$ & 8 & 8 & ND & ND \\
\hline Damaged buildings (thousands) & ND & more than 208 & $177-313$ & ND & ND & ND & ND \\
\hline
\end{tabular}

Sources: aBBC 2010, Reuters 2011; ' $\mathrm{G}$ Government of the Republic of Haiti 2010a; 'Daniell 2011; d EM-DAT 2011; ' Munich Re 2011; ${ }^{\mathrm{f}}$ Melissen 2010; ' $\mathrm{RMS}$ 2010.

\subsection{Impact of the Losses-a National-Scale Event}

The number of deaths was considerable and represents between 0.71 percent (using the average of the Radio Netherlands estimates) and 3.16 percent (using the Haitian official figure) of the country's total population. Everyone in Haiti has lost at least some acquaintances. The disaster has also created many orphans or families without breadwinners. Child trafficking has been widely reported in the press: orphans looking for a survival strategy are easy preys for some people who exploit them. Yet, precise information about this issue is difficult to find. Even prior to the earthquake, Haiti counted many orphans who constitute a particularly vulnerable group. ${ }^{\mathrm{i}}$

The number of injured made some doctors fear that the country will have to manage a generation of amputees, a concern expressed by a doctor from the NGO Médecins Sans Frontières (Doctors without Borders) who compared this situation with the Crimean war. The estimate of 200,000 people who had lost a limb appeared in the news media (The Guardian 2010) but it is difficult to know how reliable this number is. Haiti will have to live with this national injury for years to come.

According to CATDAT (Daniell 2011), economic losses account for 70.8 percent of the PPP GDP (PPP=Purchasing Power Parity), which equals 120.6 percent of the nominal GDP. The Haitian economy experienced an 8 percent negative growth in 2010. These economic losses pose particularly severe problems in a poor country like Haiti because these losses almost all correspond to vital needs. The humanitarian crisis following the disaster was therefore particularly serious. Moreover, most of the losses were not insured. Only between 30 and 150 million USD of losses were covered by insurance companies, which, at best, accounts for 1.875 percent of the total economic losses (using the "low" estimate of 8 billion USD). The earthquake has annihilated the hopes some placed in the timid improvement of the country's economy since 2005. Such a disastrous impact justifies the name "Haiti's earthquake"-it was a national event that has had and will have a major impact on the country's future.

\subsection{Huge Losses Due to Haiti's Extremely High Vulnerability}

Table 3 shows a series of factors that had a significant influence on disaster losses. Many features of the Haitian economy, society, political history, and political system contributed to amplify the impacts of the disaster. The table provides a non-exhaustive list of the different components of the vulnerability of Haiti. We chose to classify them into three categories for analytical clarity but some of them fall into two categories or are closely related to issues that belong to another category. The basic problems are poverty, social inequalities, and lack of social structures as well as a weak political system that lacks both efficiency and legitimacy.

\section{A Deficient Emergency Response}

\subsection{A Slow Response that Aggravated Losses}

Table 4 shows a short chronology of disaster response that focuses on four actors: the Haitian government, which is supposed to play the main role in disaster response as the authority of the sovereign Haitian State; the United Nations, which have a mandate in Haiti; the U.S. government, especially the U.S. army; and international NGOs, which played a major role in the organization of the disaster response.

This chronology reveals that all the main actions were taken rather late. The pace of a disaster is terribly fast and relief work has to adapt. After 72 hours, the probability of finding survivors under the rubble rapidly decreases. But the two main actors that were on the ground and had enough legitimacy to intervene, the Haitian government and the MINUSTAH, did not take any major measure during this crucial phase of the emergency, a situation that can be explained by their own difficulties since the two institutions were badly hit by the earthquake. The U.S. government reacted relatively slowly because a foreign intervention involving troops in another country is always a delicate matter to be handled with great care. 
Table 3. Haiti's vulnerability: multiple sources of fragility

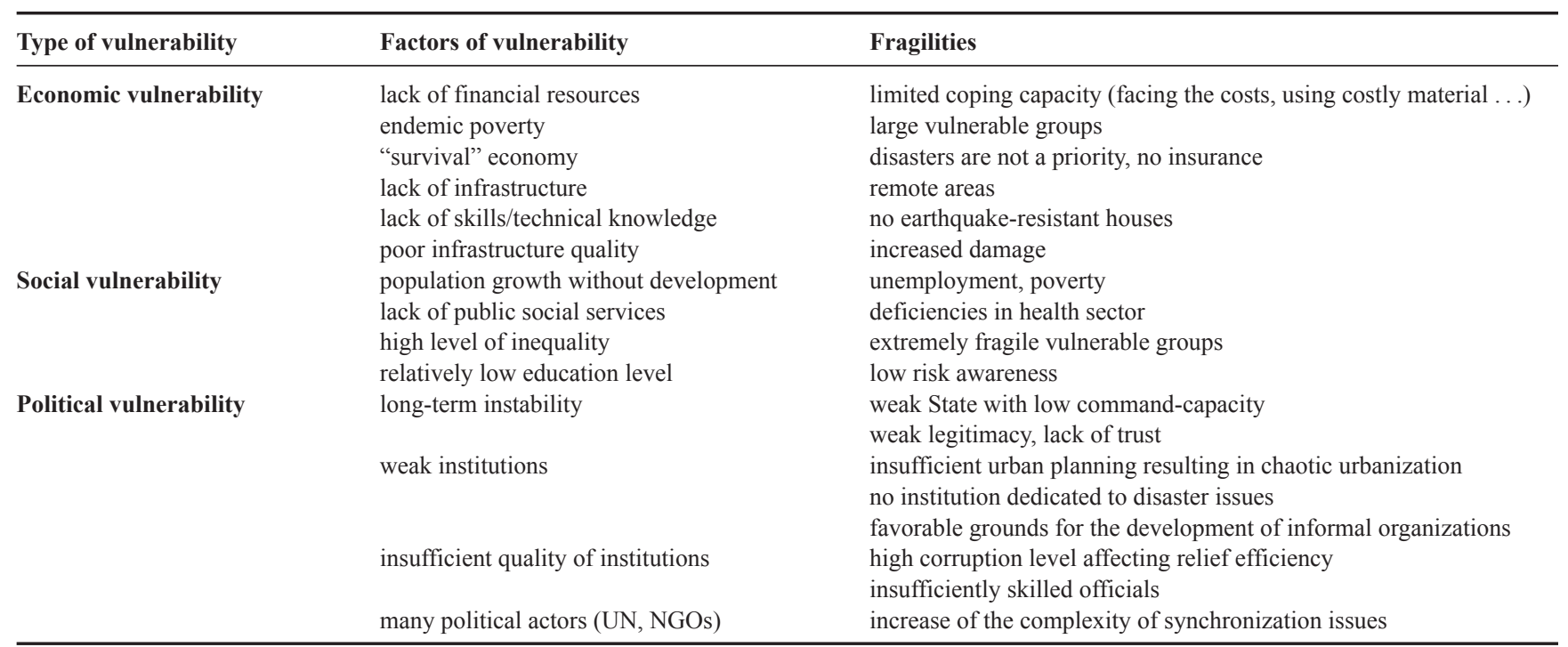

One of the most striking characteristics of this chronology is that the Haitian government has done little. Some governmental teams have taken part in rubble and corpse removal activities and the police were mobilized, but these actions were far from sufficient and met limited success. Two weeks after the earthquake, only 3433 policemen of the 6000 from the area of Port-au-Prince had responded to the government's call (AFP 2010). The Haitian government's leadership also looks quite weak: official statements were sometimes proclaimed rather late. State of emergency was not proclaimed until day 6 , even though it was obvious from day 1 that the earthquake was a major emergency for the country. This suggests that the Haitian government neither had efficient means to assess the situation rapidly nor the capacity to face the situation and meet the needs of the victims. The weak response did not help to alleviate losses. The response depended primarily on exterior actors, that is, NGOs and the U.S. army.

In Table 4, we selected some of the most important actions carried out by international NGOs, focusing on two major structures: Médecins Sans Frontières and the International Red Cross Federation (IFRC 2011) - which is not exactly a NGO. This chronology is far from exhaustive and aims mainly at providing the reader with an overview of the timing of the international humanitarian response to the disaster rather than listing all the operations undertaken by these organizations. Apart from media reports, we relied heavily on a timeline published online that aimed at spreading information about the disaster (Crisis Commons 2010). This chronology shows that international NGOs reacted quite rapidly to the disaster, but their speed of reaction was sometimes altered because it depended on supplies sent from all over the world and on transportation speed.

There are important gaps in Table 4 in that we do not provide information about local NGOs, which constitute the vast majority of the NGOs working in Haiti but are usually small.
Getting information about them is a long and difficult task. Personal initiatives and help between friends and family members also played an essential role in the disaster response: most of the Haitians who were taken out from the rubble were rescued by their comrades. Focusing here on the role played by structures such as the national government, the United Nations, the United States, or international NGOs does not mean that victims are passive. They play a key role in earthquake response.

By looking at the chronology of disaster response, one can understand that the response was too slow to meet the demands of the search and rescue work and the need to provide medical care for the injured. Many people had to wait for treatment in very difficult conditions and their state deteriorated.

\subsection{Why Did the Response not Match the Magnitude of the Disaster?}

\subsubsection{A Heavily Impacted Response System-the Catastrophe Model}

One of the reasons why the earthquake has been so destructive is that most of the structures that were supposed to deal with it were damaged by the event. This issue has been addressed by Quarantelli who proposed a "catastrophe" model, arguing that the most severe events deserve specific attention and should be treated differently from other disasters, both for research and management purposes (Quarantelli 2000, 2006). He points out that, the first characteristic of catastrophes is that most of the community-built structures are heavily impacted, which means that looking for close shelter places is often impossible, and also that the organizations which are supposed to overcome the impact of the event experience damage and cannot easily take action. The response system is therefore paralyzed. In Haiti, the 
Table 4. Chronology of disaster response to Haiti's 2010 earthquake

\begin{tabular}{|c|c|c|}
\hline Time & Haitian government & United Nations \\
\hline Day $1(01 / 12)$ & collapse of presidential palace & $\begin{array}{l}\text { collapse of the building of } \\
\text { MINUSTAH's headquarters }\end{array}$ \\
\hline Day $2(01 / 13)$ & $\begin{array}{l}\text { implementation of a mechanism to } \\
\text { work with the international } \\
\text { community }\end{array}$ & \\
\hline Day $3(01 / 14)$ & \multicolumn{2}{|c|}{$\begin{array}{l}\text { end of the } 72 \text { critical hours for rescue: no main decision had been taken } \\
\text { (Haitian government }+ \text { UN + U.S.) }\end{array}$} \\
\hline Day $4(01 / 15)$ & \multirow{2}{*}{\multicolumn{2}{|c|}{$\begin{array}{l}\text { government teams claim to have } \\
\text { cleared } 9000 \text { corpses; protests } \\
\text { against government }\end{array}$}} \\
\hline Day $5(01 / 16)$ & & \\
\hline Day $6(01 / 17)$ & $\begin{array}{l}\text { Haitian State proclaims state of } \\
\text { emergency; police open fire on } \\
\text { looters }\end{array}$ & $\begin{array}{l}\mathrm{UN} \text { says they are ready to take } \\
\text { action }\end{array}$ \\
\hline \multicolumn{3}{|l|}{ Day $7(01 / 18)$} \\
\hline Day $8(01 / 19)$ & & $\begin{array}{l}\text { Security Council allows the sending } \\
\text { of } 2000 \text { soldiers and } 1500 \\
\text { policemen }\end{array}$ \\
\hline
\end{tabular}

Day $9(01 / 20)$

$$
\text { policemen }
$$

$\begin{array}{ll}\begin{array}{l}\text { about } 9000 \text { soldiers } \\ \text { sent }\end{array} & \text { first supplies distributed by IOM } \\ \begin{array}{l}\text { creation of Joint Task } \\ \text { Force Haiti by the } \\ \text { Ministry of Defense }\end{array} & \begin{array}{l}\text { 50-bed field hospitals of Red } \\ \text { Cross arrive; MSF had treated } \\ \text { about 2000 persons }\end{array} \\ & \text { MSF plane not allowed to land }\end{array}$

first air drops

$$
\begin{aligned}
& \text { two Red Cross flights with } \\
& \text { supplies for more than } 32,000 \\
& \text { families are expected } \\
& \text { another MSF plane is diverted to } \\
& \text { Dominican Republic } \\
& \text { more than } 130 \text { surgeries a day by } \\
& \text { MSF; } 100 \text { tons of relief supplies } \\
& \text { have already arrived; most } \\
& \text { important Red Cross deployment } \\
& \text { in a single country }
\end{aligned}
$$

Red Cross Hope for Haiti telethon airs
Day $10(01 / 21)$

Day $11(01 / 22)$

Day $12(01 / 23)$

Day $19(01 / 30)$

Day $20(01 / 31)$

Day $21(02 / 01)$

Day $23(02 / 03)$

Day $28(02 / 08)$

Day $34(02 / 14)$

Day $39(02 / 19) \quad$ decision to use public and private land for resettlement

Day $43(02 / 23) \quad$ president Preval says that cleaning the rubble will take about 3 years

Day $50(03 / 02) \quad$ government reveals resettlement plans
$\mathrm{UN}$ is preparing a large-scale food distribution program. Goal: reaching 2 million people in 2 weeks (WFP)

UN plan starts to be implemented

UN Development Program employing over 12,000 Haitians for rubble clearance

Bill Clinton named chief of the UN reconstruction efforts

UNFAO starts a cash-for-work program

UN launches a record call for funding (1.44 billion dollars)
Port-au-Prince divided into 16 sections. U.S. army supplies security, NGOs distribute supplies

peak of U.S. military deployment: 22,000 men in Haiti

MSF has more than 3000 staff
U.S. cancel Haitian
debt

Day $65(03 / 17) \quad$ release of a national recovery plan

Main sources: Crisis Commons 2010; Doctors Without Borders 2011; Government of the Republic of Haiti 2010a; United Nations Foundation 2011. Abbreviations: IOM: International Office for Migrations; MINUSTAH: Mission des Nations Unies pour la stabilisation en Haiti; MSF: Médecins Sans Frontières; UNFAO: Food and Agriculture Organization of the United Nations; WFP: World Food Program. 
presidential palace and the building of the MINUSTAH's headquarters both collapsed because of the earthquake and lost important staff. Mission head Hedi Annabi and deputy head Luiz Carlos Da Costa both died under the rubble, 83 staff members were killed, and 32 were reported missing. The Haitian government's staff has also been badly affected by the disaster. About 17 percent of the Haitian central government staff died in the collapse of the presidential palace, but the government did not lose its leading officials as the UN Mission did. Damage to the presidential palace, the most important government building, was a very important problem. The necessity to welcome many foreign leaders and high UN officials with the provision of appropriate security measures also kept the Haitian government away from ground operations. Apart from the UN and the Haitian government, staff from different NGOs also paid a heavy tribute to this disaster (Haver 2011). Health infrastructures have been impacted with at least eight hospitals and/or health centers unable to function because of earthquake damage, so many injured people had to wait for a long time before getting medical assistance. Damage to transportation infrastructures (Crisis Commons 2010) also had a strong adverse impact on disaster response since the sending of relief supplies was hampered: the seaport could not work because of extensive damages. Apart from the Dominican Republic, the only link between Haiti and the rest of the world was its international airport. Although it also suffered from the earthquake, flights quickly resumed and the airport, which was managed by the U.S. army, became the main platform for disaster supplies. Damage to roads delayed the delivery of relief goods to some of the worst-hit areas such as Jacmel. Telephone and radio communications were disrupted, which slowed the spreading of information about the disaster and complicated the coordination of disaster response.

The second characteristic of catastrophes Quarantelli points out is that local officials are unable to undertake their usual work role. This was clearly true in the case of the Haitian earthquake and the problem was aggravated by the fact that there never has been a defined role for local officials in Haiti in the case of an earthquake. Thirdly, Quarantelli estimates that the impact of a catastrophe is aggravated by the absence of available help from nearby communities. Haiti's disaster area included the whole Port-au-Prince agglomeration and part of its neighboring areas. With all other places in Haiti poorer than the capital city, they could not significantly contribute to relief efforts. Support from the Dominican Republic can be seen as an exception but treating it as "relief from the neighborhood" is debatable. Fourth, most, if not all, of the everyday community functions are sharply and concurrently interrupted in catastrophes. This was of course the case in Haiti; disruption of communications and telecommunications, lack of power supply, disruption of all business chains, and suspension of class in schools lasted for three months. According to Quarantelli, the fifth characteristic of catastrophes is that the mass media system, especially in recent times, socially constructs catastrophes even more than disasters. The huge international media coverage of the Haitian earthquake undoubtedly made it fit this definition. Quarantelli concludes by stating that, in the case of catastrophes, the political arena is even more important than in the case of other disasters. The political system is not necessarily overwhelmed by disasters, but shows its limits in the face of catastrophes. The difficulties and lack of action of the Haitian government, the hardships experienced by the UN, the massive American military intervention and the debates around it, the synchronization issues posed by the convergence of many NGOs towards the disaster area and, above all, the organization of the presidential elections that led to the discarding of the ruling party's candidate and to the unexpected victory of Michel Martelly all show how this disaster has reshaped the political arena in Haiti. The earthquake had an adverse impact on the legitimacy of the government, its party, and even on the whole Haitian political class. In such a context, Michel Martelly, a new-comer in politics, got elected.

\subsubsection{Who Leads? - Synchronization between Many Heterogeneous Actors}

The disaster drew a lot of attention from all over the world and different actors converged on Port-au-Prince after the earthquake. In a situation in which the two actors who are supposed to assume leadership (the Haitian government and MINUSTAH) were terribly weakened, synchronization issues that are a recurrent problem in the aftermath of disasters were exacerbated. The deficiencies of the Haitian government appear to be the main problem since it is in theory the most appropriate institution to take the lead in national relief efforts. Strengthening the capacity of the government is, in theory, the most appropriate solution but would be quite difficult to implement. NGOs can appear as a symptom of state failure and cannot really replace government initiative (Wargny 2011). In spite of many difficulties, the various actors of disaster response were aware of the importance of synchronization issues and made efforts to address them. The Haitian government quickly created a mechanism to work with the international community and regularly held meetings with different actors. Information sharing among NGOs, particularly thanks to the use of the internet, and meetings also played a role to synchronize operations.

In spite of these efforts, the situation was quite chaotic. We try to briefly sum up the main problems that affected synchronization and earthquake response. These issues have been addressed in two reports (Haver 2011; IASC 2010). The list in Table 5 is mainly based on them and on press reports.

\section{Conclusions}

The 2010 Haitian earthquake will remain one of the deadliest natural disasters in history. This major event has drawn massive attention from the media and the international 
Table 5. Main obstacles to synchronization of disaster response in the $\mathbf{2 0 1 0}$ Haiti earthquake

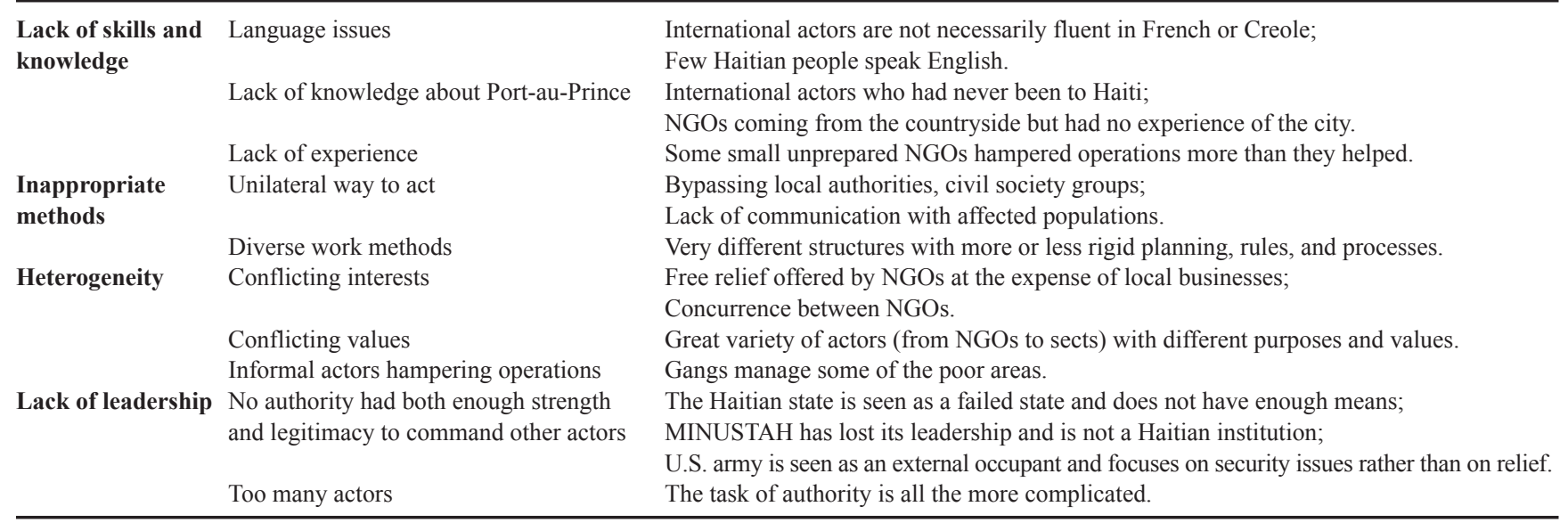

community - with a record amount of donations, but it is still difficult to have a clear view of it since the losses are particularly hard to estimate, because of Haiti's endemic poverty, weak administrative structures, and extra constraints posed by this disaster. The imprecise understanding of the losses caused by this disaster is both a symptom of the fragility of the country and an additional difficulty; decisions must be made without accurate assessments of the situation. This very fragility of Haiti must also be seen as the most important explanation of the terrible human losses the island suffered. Under such difficult circumstances, disaster response did not manage to match the magnitude of the hardships brought by the earthquake. As a vulnerable society in which the response system had been damaged, Haiti had to rely on external actors, a situation that raises a number of issues regarding synchronization of relief work as well as political legitimacy.

As a case of massive international intervention that lead to a tremendous multiplication of the number of actors in disaster response - a phenomenon that is common with disasters but reached a rare magnitude in Haiti - this disaster could be a very interesting case study of the synchronization of disaster response and recovery processes. A better understanding of these issues could be helpful to improve the efficiency of post-disaster actions. In the case of Haiti, reducing vulnerability to disaster certainly implies a focus on specific disaster measures and on a better integration of disaster issues in economic development plans, building methods or norms, and land-use planning. But the most crucial issues lie in the improvement of the country's economic, social, and political development. Addressing the root causes of Haiti's vulnerability should lead to an improved capacity for disaster reduction.

\section{Acknowledgments}

The authors would like to thank the Open Foundation of State Key Laboratory of Earth Surface Processes and Resource Ecology at Beijing Normal University for providing support for this study (Grant No. 2009-KF-14). They also express their gratitude towards Mr. Michel Korinman who supervises Laurent Hou's work in France. Many thanks also go to Mr. Jean-Marie Theodat who is currently working hard to redevelop the Haitian higher education system.

\section{Note}

i The 2009 UNICEF estimate is as high as 440,000 (http://www.unicef. org/infobycountry/haiti_statistics.html).

\section{References}

AFP (Agence France-Presse). 2010. Haiti: The Police Points to New Forms of Violence (Haïti: la police pointe de nouvelles formes de violence après le séisme). January 28. http://reliefweb.int/node/ 343342.

Asian Disaster Reduction Center. 2002. Top 25 Natural Disasters in Japan according to Number of Killed (1901-2000). http://www.adrc. asia/publications/databook/ORG/databook_20th/JPN.pdf.

BBC (British Broadcasting Corporation). 2010. Haiti will not Die, President Rene Preval Insists. February 12. http://news.bbc.co.uk/2/ hi/8511997.stm.

Bilham, R. 2010. Lessons from the Haitian Earthquake. Nature 463 (7283): 878-79. http://www.nature.com/nature/journal/v463/n7283/ full/463878a.html.

Cavallo, E. A., A. Powell, and O. Becerra. 2010. Estimating the Direct Economic Damage of the Earthquake in Haiti. Inter-American Development Bank Working Paper Series No. IDB-WP-163.

CIA (Central Intelligence Agency). 2011. World Factbook. https://www. cia.gov/library/publications/the-world-factbook/geos/ha.html.

Crisis Commons. 2010. The Haiti Timeline. http://wiki.crisiscommons. org/wiki/The_Haiti_Timeline.

Daniell, J. 2011. Damaging Earthquakes Database 2010 - The Year in Review. http://earthquake-report.com/damaging-earthquakes-2010/.

Doctors Without Borders. 2011. Haiti Earthquake 2010. http://www. doctorswithoutborders.org/news/allcontent.cfm?id=208.

EM-DAT (Emergency Events Database-International Disaster Database of the Centre for Research on the Epidemiology of Disasters). 2011. Top 10 Most Important Earthquake (Seismic Activity) Disasters for the Period 1900 to 2011 Sorted by Numbers of Killed at the Country Level; Top 10 Most Important Earthquake (Seismic Activity) 
Disasters for the Period 1900 to 2011 Sorted by Numbers of Total Affected People at the Country Level. http://www.emdat.be/.

Encyclopædia Britannica Online. 2011. Kobe Earthquake of 1995. http://www.britannica.com/EBchecked/topic/873249/Kobe-earthquake-of-1995.

Government of the Republic of Haiti. 2010a. Action Plan for National Recovery and Development of Haiti - Immediate Key Initiatives for the Future. March 17. http://www.interaction.org/document/ action-plan-national-recovery-and-development-haiti-immediatekey-initiatives-future.

—. 2010b. Haiti Earthquake PDNA: Assessment of Damage, Losses, General and Sectoral Needs. http://www.refondation.ht/resources/ PDNA_Working_Document.pdf.

The Guardian. 2010. Haiti Earthquake Creating a Generation of Amputees, Doctors Warn. January 21. http://www.guardian.co.uk/world/ 2010/jan/21/haiti-doctors-warn-amputee-crisis.

Guha-Sapir, D., D. Hargitt, and P. Hoyois. 2003. Thirty Years of Natural Disasters 1974-2003: The Numbers. Université Catholique de Louvain, Louvain.

Haver, K. 2011. Haiti Earthquake Response Mapping and Analysis of Gaps and Duplications in Evaluations. ALNAP (Active Learning Network for Accountability and Performance in Humanitarian Action)

IASC (Inter-Agency Standing Committee). 2010. Response to the Humanitarian Crisis in Haiti Following the 12 January 2010 Earthquake-Achievements, Challenges and Lessons to be Learned. July 14. http://www.humanitarianinfo.org/iasc/pageloader.aspx?page= content-news-newsdetails\&newsid=143.

ICRC (International Committee of Red Cross). 2010. Haiti Earthquake: ICRC Relief Effort Gathers Pace. http://www.icrc.org/eng/resources/ documents/update/haiti-update-140110.htm.

IFRC (International Federation of Red Cross). 2011. Who We Are. http:// www.ifrc.org/en/who-we-are/.

IHSI (Institut Haitien de Statistique et d'Informatique). 2009. Total Population, Population Above 18, Households and Estimated Densities for 2009 (Population totale, population de 18 ans et plus ménages et densités estimées en 2009). http://www.ihsi.ht/pdf/projection/ POPTOTAL\&MENAGDENS_ESTIM2009.pdf.

Kobe City Official Website. 2011. Population. http://www.city.kobe. lg.jp/foreign/english/information/information_03.html.

Lacassin, R., Y. Klinger, N. Feuillet, R. Armijo, and P. Tapponier. 2010. Preliminary Evaluation of the Haiti January 12, 2010, Earthquake. http://www.ipgp.fr/files_lib/831_Haiti_Report_IPG-TECTO.pdf.
Melissen, H. J. 2010. Haiti Quake Death Toll Well under 100,000. February 23. http://www.rnw.nl/english/article/haiti-quake-deathtoll-well-under-100000.

Munich Re. 2011. Overall Picture of Natural Catastrophes in 2010. http://www.munichre.com/en/media_relations/press_releases/2011/ 2011_01_03 press_release.aspx.

Noy, I. $200 \overline{9}$. The Macroeconomic Consequences of Disasters. Journal of Development Economics 88 (2): 221-31.

Prépetit, C. 2008. Earthquakes in Haiti: Myth or Reality? (Tremblements de terre en Haïti: mythe ou réalité ?). http://www.lnbtp.gouv.ht/ publications/seisme-haiti.pdf.

- 2009. Are We Living on a Time Bomb? (Vivons nous sur une poudrière ?). Interview by Le Nouvelliste. http://www.lenouvelliste. com/articles.print/1/76637.

Quarantelli, E. L. 2000. Emergencies, Disasters and Catastrophes are Different Phenomena (Preliminary paper). http://dspace.udel.edu: 8080/dspace/bitstream/handle/19716/674/PP304.pdf?sequence=1.

_ 2006. Catastrophes are Different from Disasters: Some Implications for Crisis Planning and Managing Drawn from Katrina. http:// understandingkatrina.ssrc.org/Quarantelli/.

Reuters. 2011. Haiti Revises Quake Death Toll up to over 316,000. January 12. http://www.reuters.com/article/2011/01/12/haiti-quaketoll-idUSN1223196420110112.

RMS (Risk Management Solutions). 2010. RMS FAQ: 2010 Haiti Earthquake and Caribbean Earthquake Risk. January 22. http://www. rms.com/publications/Haiti_Earthquake_FAQ.pdf.

Transparency International. 2011. Corruption Perceptions Index 2011. http://www.transparency.org/policy_research/surveys_indices/cpi/ 2010.

United Nations Foundation. 2011. Haiti Earthquake Response. http:// www.unfoundation.org/our-impact/stories-of-impact/health-datadisaster-relief/haiti-earthquake-response.html.

USGS (U.S. Geological Survey). 1996. Kobe Earthquake Was Deadliest, But Not Largest In '95. http://www.usgs.gov/newsroom/article. asp?ID=744.

—. 2010. Magnitude 7.0 - HAITI REGION. http://earthquake.usgs. gov/earthquakes/recenteqsww/Quakes/us2010rja6.php.

- 2011a. Earthquake Facts and Statistics. January 3. http://earthquake.usgs.gov/earthquakes/eqarchives/year/eqstats.php.

- 2011b. Magnitude/Intensity Comparison. February 22. http:// earthquake.usgs.gov/learn/topics/mag_vs_int.php.

Wargny, C. 2011. Haiti in the Hands of the NGOs. Le Monde Diplomatique, January 6. http://mondediplo.com/2011/01/06haiti.

World Bank. 2009. Database. http://data.worldbank.org/country/haiti.

Open Access This article is distributed under the terms of the Creative Commons Attribution License which permits any use, distribution, and reproduction in any medium, provided the original author(s) and source are credited. 